\title{
Evaluation of Lentil Genotypes (Lens culinaris Medikus) for Growth and Yield Performances across Climate Conditions of Central Highlands of Ethiopia
}

\author{
Eba Muluneh Sorecha*, Nano Alemu Daba \\ College of Agriculture and Environmental Sciences, Haramaya University, P.O.Box: 138, Dire Dawa, Ethiopia
}

A R T I C L E I N F O
Research Article
Received 06 May 2018
Accepted 06 September 2018

Keywords:

Climate

Genotype

Growth

Lentil

Yield

*Corresponding Author:

E-mail: ebamule1@gmail.com

\begin{abstract}
A B S T R A C T
Lentil crop has largely been affected by global climate changing, particularly, due to rainfall and temperature changing and variability. Hence, the experiment was conducted in Central Highlands of Ethiopia, namely Akaki, Chefe Donsa and Bishoftu Agricultural Research Centre, in the 2009 and 2010 cropping seasons to assess the genotypic variation of lentil for growth and yield performances. Five lentil genotypes viz. 87S-93549 X EL103-16, 87S-93549 X EL-103-9-1, Alemaya X FLIP 88-41L-02-AK-14, Alemaya X FLIP 88-41L-02-AK-6 were arranged in randomized complete block design with four replications at all locations. The result of study revealed that the genotype 87S-93549 X EL-103-9-1 produced the highest seed yield of 1985.90 and $2500.00 \mathrm{~kg} \mathrm{ha}^{-1}$ during 2009 and 2010 cropping seasons, respectively, at Akaki. On the other hand, the genotype Alemaya X FLIP 88-41L-02-AK-14 gave the highest seed yield $\left(4189.1 \mathrm{~kg} \mathrm{ha}^{-1}\right)$ at Chefe Donsa in 2009 cropping season. The genotype X FLIP 88-41L-02-AK-14 was found to be the earliest in physiological maturity, accounting 128.75 days, and the genotype 87S93549 X EL-103-9-1 had yield advantage of 27.6\% over the local check at Chefe Donsa in the 2010 cropping season. Generally, all lentil genotypes were performed better at Chefe Donsa, followed by at Akaki and Bishoftu locations during both cropping seasons. Rainfall and temperature conditions have enormous influences on the growth and yields performances of lentil genotypes at all research locations. The study inspires other studies to be conducted on other factors than climate events thwarting the production of lentil crops in the study areas.
\end{abstract}

DOI: https://doi.org/10.24925/turjaf.v6i11.1575-1581.2004

\section{Introduction}

Lentil (Lens culinaris Medikus) is one of the most ancient annual food crops that have been grown as important food sources for human consumption for over 8,000 years (Dhuppar et al., 2012). It is widely grown in Egypt, central and southern Europe, the Mediterranean basin, Afghanistan, China, Ethiopia, India, Pakistan and later to the new world, including Argentina, Chile, Colombia, Latin America, Mexico and more recently in Canada (Cokkizgin and Munqez, 2013). The total lentil cultivated area in the world is estimated around 5.5 million hectares with annual production and productivity of 6.3 million tons and $1152 \mathrm{~kg} \mathrm{ha}^{-1}$, respectively (FAO, 2016).

Ethiopia is considered as a centre of diversity for lentil and currently lentil is an important pulse crop (Edossa et al., 2007). This makes Ethiopia one of the major lentilproducing countries in Africa and is listed in the top ten countries in the world (FAO, 2016). It is one of the major highland pulses of Ethiopia that grows in rotation with teff (one of the staple food crop of Ethiopians), wheat and barley particularly on the heavy black soils (vertosols) (Jarso et al., 2009). Lentil is an important part of the farming system and essential to nutrition in the subsistence farming community in Ethiopia (Korbu, 2009). In such culture, a yield advantage of the succeeding cereal crop is realized as a result of the fixed nitrogen by the predecessor legume and also due to breakage of the life cycle of important diseases and insect pests (Bedard, et al., 2010).

Lentil plays a significant role in human and animal nutrition and in maintenance and improvement of soil fertility (Frederick et al., 2006; Sarker and Kumar, 2011). Its cultivation enriches soil nutrient status by adding nitrogen, carbon and organic matter, which promote sustainable cereal-based systems of crop production (Sarker and Kumar, 2011). It is cultivated for its seed and mostly eaten as split (Iqbal et al., 2006), locally known as 'misir kik'. The primary product of lentil is its seed, which has relatively higher contents of protein, carbohydrate and calories than other legumes (Muehlbauer et al., 1985). It 
is the most desired crop because of its high average protein content and fast cooking characteristic in many lentil-producing regions. It can be used as a main dish, soup, side dish, or in salads. Protein concentration of lentils reportedly range from 22 to $34.6 \%$, and $100 \mathrm{~g}$ of dried lentil seeds contain 340-346 g calories, $12 \%$ moisture, $20.2 \mathrm{~g}$ protein, $0.6 \mathrm{~g}$ fat, $65.0 \mathrm{~g}$ total carbohydrate, about $4 \mathrm{~g}$ fiber, $2.1 \mathrm{~g}$ ash, $68 \mathrm{mg} \mathrm{Ca}, 325$ $\mathrm{mg} \mathrm{P}, 7.0 \mathrm{mg} \mathrm{Fe}, 29 \mathrm{mg} \mathrm{Na}, 780 \mathrm{mg} \mathrm{K}, 0.46 \mathrm{mg}$ thiamine, $0.33 \mathrm{mg}$ riboflavin, $1.3 \mathrm{mg}$ niacin (Muehlbauer et al., 1985; Adsule et al., 1989). Husks, dried leaves, stems, fruit walls and bran (residues) can be fed to livestock. Lentil residues contain about $10.2 \%$ moisture, $1.8 \%$ fat, $4.4 \%$ protein, $50 \%$ carbohydrate, $21.4 \%$ fiber, and $12.2 \%$ ash (Muehlbauer et al., 1985).

Lentil is amongst the principal cool season food legumes in Ethiopia too (Joseph, 2014). It is widely grown in areas having altitudinal range of 1700-2400 meters above sea level with annual rainfall ranging from $700-2000 \mathrm{~mm}$ in Ethiopia (Korbu, 2009). Lentil is commonly sown towards end of July or in August in Ethiopia and particularly grown as an important crop in Amhara, Oromiya and Tigray Regions and some parts of Southern Nations, Nationalities and Peoples' Region (Korbu, 2009). It is usually well-adapted to various soil types ranging from sandy to clay-loam when there is good internal drainage (Ozdemir, 2002). It appears very sensitive to waterlogged field conditions and, even with short period of exposure to water-logging, can cause the crop to die easily (Brennan et al., 2002). It performs best on deep, sandy-loam soils with high phosphorus and potassium contents. High humidity with excessive rainfall during growing season promotes vegetative growth and caused lodging, which reduces later good yield and seed quality.

In lentil, Anbessa and Bejiga (2002) and Keneni et al. (2012) reported highly significant variations of growth and yield traits and identified number of superior genotypes and suggested potential of germplasm in obtaining superior varieties. Lentil research is in its infancy stage and limited information is available on the performance of growth and yield traits in Ethiopia in general and in central highlands of Ethiopia in particular. Assessing genetic variation of the available lentil genotypes could help to devise suitable breeding strategy in lentil. Results on morphological and recently molecular evaluation of lentil genotypes obtained from other regions of the world cannot be applied directly to Ethiopia due to differences in environmental conditions.

Although the lentil crop has evolved appropriate stress tolerance strategies, they are largely affected by global climate change that in turn brought a number of environmental challenges. Except few findings (Getahun, 2016) and review works (Abraham, 2015), there are no research works done in depth, which evaluated the lentil genotypes under temperature and rainfall change and variability on the growth and yield performance in the Central Highlands of Ethiopia, given the essentiality of this crop. Therefore, this study was conducted to evaluate the lentil genotypes for growth and yield performance across climate conditions of Central Highlands of Ethiopia.

\section{Materials and Methods}

\section{Description of the Study Area}

The experiments were conducted at three locations, namely Akaki, Chefe Donsa and Bishoftu for two cropping seasons (2009-2010). The locations were purposively selected for their potential in lentil production in the Central Highlands of Ethiopia (Figure 1). Akaki is found at $30 \mathrm{~km}$ north of Bishoftu and geographically located at $08^{\circ} 53$ '39' North latitude and 38 $49^{\prime} 13^{\prime \prime}$ East longitude having altitude of 2400 metre above sea level. It has a soil dominated by heavy clay and Eutric Vertisols. The area is hot to warm sub-humid climate (NMA, 2007). Bishoftu is located $47 \mathrm{~km}$ east of Addis Ababa and geographically $8.73^{\circ} \mathrm{N}$ latitude and $38.98^{\circ} \mathrm{E}$ longitude with elevation ranging from 1931 to 2097 metre above sea level. The soil textural class in the area is loam and having the Haplic Andosols, Vitric Andosols and Vertisols (Mesfin and Tekalign, 2011). The area receives an annual average rainfall of about $776 \mathrm{~mm}$ based on the climate data analysis of 1980-2012 periods (Sorecha et al., 2017). The annual mean maximum and minimum temperatures are 25.5 and $10.5^{\circ} \mathrm{C}$, respectively (NMA, 2007). Chefe Donsa is located $35 \mathrm{~km}$ east of Bishoftu and geographically located at $08^{\circ} 57^{\prime} 15^{\prime}$ "North latitude and $39^{\circ} 06^{\prime} 04^{\prime \prime}$ East longitude having an altitude of 2450 metre above sea level. Heavy clay soil textural class and Eutric Vertisol soil types dominate the area. Similar to Akaki, the area is categorized as hot to warm sub-humid climate (NMA, 2007).

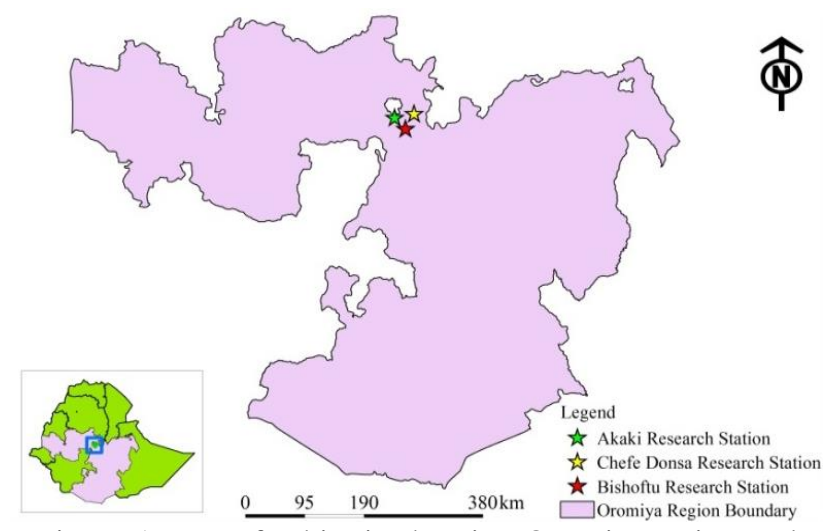

Figure 1 Map of Ethiopia showing Oromia Region and the three districts of the study area

\section{Experimental Design and Treatments}

Five lentil genotypes, namely 87S-93549 X EL-10316, 87S-93549 X EL-103-9-1, Alemaya X FLIP 88-41L02-AK-14, Alemaya X FLIP 88-41L-02-AK-6, and local check (genotype used by farmers in the area, Alemaya), were collected from the Ethiopian Institute of Agricultural Research Center (EIAR). The collected materials were used for experiments conducted at Akaki, Bishoftu and Chefe Donsa Agricultural Research Center location farms during late June to mid-July 2009-2010. The trials were laid out in a randomized complete block design (RCBD) with four replications at all locations. The unit plot size was $3.2 \mathrm{~m}^{2}$ ( $4 \mathrm{~m}$ x $0.8 \mathrm{~m}$ ) with spacing of $20 \mathrm{~cm}$ between rows and $2 \mathrm{~cm}$ between plants (after thinning). Planting was done via drilling at seed rate of 800 seeds/plot, meaning, 200 seeds per row. All other recommended 
agronomic practices were kept normal and uniform to ensure normal plant growth and development.

Number of days to flowering (DF) was recorded as the number of days from planting to the time when $50 \%$ of the 10 pre-tagged plants showed first flower. Days to $90 \%$ physiological maturity (DM) was recorded in each plot, as the number of days from planting to when $90 \%$ of the 10 pre tagged plant leaves showed yellow colour and their pods turned yellow. Seed yield (YLD) $(\mathrm{kg})$ was recorded from each net plot area. The moisture content was determined for each treatment and the seed yield was adjusted at $10 \%$.

Therefore, yield gap analysis has been done quantifying the differences between potential yield of different genotypes considered and the local check genotype (Liang et al., 2011). It's calculated using the formula:

$$
\Delta \mathrm{Y}=\frac{\mathrm{Y}_{\mathrm{s}}-\mathrm{Y}_{\mathrm{b}}}{\mathrm{Y}_{\mathrm{b}}} \times 100
$$

Where $\Delta \mathrm{Y}=$ change of yield, $\mathrm{Ys}=$ potential yield of genotypes, $\mathrm{Yb}=$ local variety yield

\section{Data Analysis}

The data were subjected to analysis of variance (GLM procedure) using SAS software program version 9.2 (SAS Institute, 2003). Homogeneity of variances was evaluated using the F-test as described by (Gomez and Gomez, 1984). Least significant difference (LSD) test at 5\% probability level was employed to separate treatment means where significant treatment differences existed. The three locations and two seasons were considered as different environments because of heterogeneity of variances and F- test was significant for most of the parameters studied. Therefore, data were not combined for analysis.

\section{Results and Discussion}

Evaluating Lentil Genotypes for Growth and Yield Performance at Akaki

The analysis of variance revealed that differences among genotypes were significant $(\mathrm{P} \leq 0.01)$ on number of days to $50 \%$ flowering and seed yield over the two cropping seasons, 2009 and 2010 (Table 1). Lentil genotypes during 2009 cropping season attained flowering earlier by 3 days than 2010 cropping season. This might be due to the higher temperature and rainfall at early crop emergence during the 2009 cropping season compared to 2010 cropping season (Figure 2). High temperatures reduced pod set in chickpea by reducing pollen viability and pollen production per flower (Devasirvatham et al., 2012). Stigma receptivity can also be affected at very high temperatures $\left(\geq 40 / 30^{\circ} \mathrm{C}\right)$ leading to failure of fertilization (Kumar et al., 2012). The results revealed that for all genotypes, except 87S-93549 X EL103-16, days to flowering was statistically in parity with local check during the 2009 cropping season. However, during 2010 cropping season all genotypes attained flowering earlier than the local check (Table 1).

The evaluation of lentil genotypes for $90 \%$ days to physiological maturity was followed similar trend during both cropping seasons. The physiological maturity of the genotype 87S-93549 X EL-103-16 was earlier by 8 and 5 days during 2009 and 2010 cropping seasons, respectively, over the local check genotype.

The genotype 87S-93549 X EL-103-9-1 had the highest seed yield (1985.90 and $2500 \mathrm{~kg} \mathrm{ha}^{-1}$ during 2009 and 2010 cropping seasons, respectively), which was in statistical parity with the seed yield obtained from the genotype Alemaya X FLIP 88-41L-02-AK-6 and Alemaya during the 2009 cropping (Table 1).

Yield variation between the cropping seasons could be the influence of climatic condition. Generally, the genotype 87S-93549 X EL-103-16 produced the lowest seed yield with 47 and $10.2 \%$ less than the local check, Alemaya, during 2009 and 2010 cropping seasons, respectively. The present result also indicated that the genotypes 87S-93549 X EL-103-9-1, Alemaya X FLIP 88-41L-02-AK-14, and Alemaya X FLIP 88-41L-02-AK6 had yield advantages of $22.2,13.4$ and $12.1 \%$ over the local check, respectively (Table 1). However, the genotype 87S-93549 X EL-103-16 was the earliest in reaching $90 \%$ physiological maturity, taking only 98 and 109 days during 2009 and 2010 cropping season, respectively.

The study revealed that the yields of lentil at Akaki location depended mainly on the rainfall and temperature parameters. In 2009 cropping season, the lowest yield was recorded due to the lowest amount of rainfall recognized, i.e. below $100 \mathrm{~mm}$ accompanied with high temperature during the critical periods for lentil growth (August and September) (Figure 2). In contrast, by 2010 cropping season, the rainfall received was better, i.e. $250 \mathrm{~mm}$ and good yields were recorded for all lentil genotypes, with the exception of the genotype 87S-93549 X EL-103-16 that adversely affected by weather conditions and, as a result, the yield declined below the local genotype (Figure 2).

Table 1 Mean seed yield and growth data of lentil genotypes tested at Akaki in 2009 and 2010 cropping seasons

\begin{tabular}{|c|c|c|c|c|c|c|c|c|}
\hline \multirow{2}{*}{ Genotype } & \multicolumn{4}{|c|}{2009 Cropping Season } & \multicolumn{4}{|c|}{2010 Cropping Season } \\
\hline & $\mathrm{DF}$ & DM & SY & $\Delta \mathrm{SY}$ & DF & DM & YLD & $\Delta S Y(\%)$ \\
\hline 87S-93549 X EL-103-16 & $42.4^{\mathrm{c}}$ & $98.25^{\mathrm{b}}$ & $987.50^{c}$ & -47.0 & $45.50^{\mathrm{c}}$ & $109.00^{\mathrm{b}}$ & $1837.50^{\mathrm{d}}$ & -10.2 \\
\hline 87S-93549 X EL-103-9-1 & $48.5^{\mathrm{ab}}$ & $107.5^{\mathrm{a}}$ & $1985.90^{\mathrm{a}}$ & 7.3 & $51.25^{\mathrm{b}}$ & $115.25^{\mathrm{ab}}$ & $2500^{\mathrm{a}}$ & 22.2 \\
\hline Alemaya X FLIP 88-41L-02-AK-14 & $50.25^{\mathrm{a}}$ & $104.25^{\mathrm{a}}$ & $1282.80^{\mathrm{bc}}$ & -30.7 & $49.50^{\mathrm{b}}$ & $116.75^{\mathrm{a}}$ & $2318.75^{b}$ & 13.4 \\
\hline Alemaya X FLIP 88-41L-02-AK-6 & $48.5^{\mathrm{ab}}$ & $105^{\mathrm{a}}$ & $1623.40^{\mathrm{ab}}$ & -12.3 & $49.75^{\mathrm{b}}$ & $115.75^{\mathrm{ab}}$ & $2293.75^{b}$ & 12.1 \\
\hline Local (Alemaya) & $47.5^{\mathrm{b}}$ & $106^{\mathrm{a}}$ & $1851.60^{\mathrm{ab}}$ & - & $54.00^{\mathrm{a}}$ & $113.5^{\mathrm{ab}}$ & $2045.31^{c}$ & - \\
\hline $\mathrm{CV}(\%)$ & 2.97 & 2.67 & 25.38 & & 2.89 & 4.00 & 3.37 & \\
\hline $\operatorname{LSD}(0.05)$ & 2.12 & 4.20 & 591.54 & & 2.18 & 6.89 & 111.53 & \\
\hline
\end{tabular}

Means followed by the same letter within the same column are not significantly different from each other at $\mathrm{P}=0.05$ level of significance,

$\Delta \mathrm{SY}=$ Change in Seed Yield $(\%), \mathrm{CV}=$ Coefficient of variation, $\mathrm{DF}=$ Days to flowering, $\mathrm{DM}=$ Days to physiological maturity,

LSD = Least significant difference, $S Y=$ Seed Yield $\left(\left(\mathrm{kg} \mathrm{ha}^{-1}\right)\right.$ 


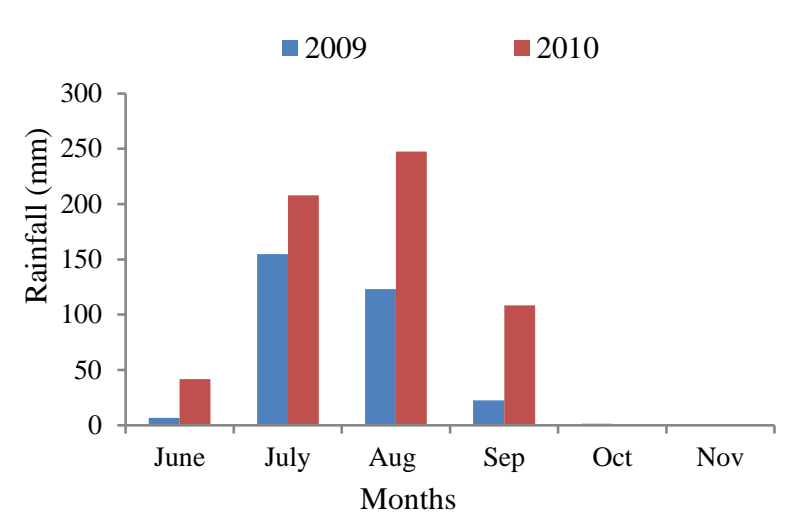

(a)

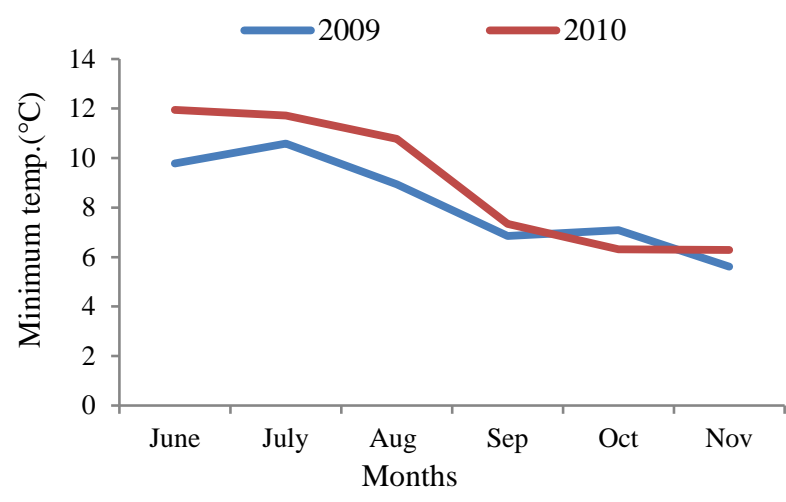

(b)

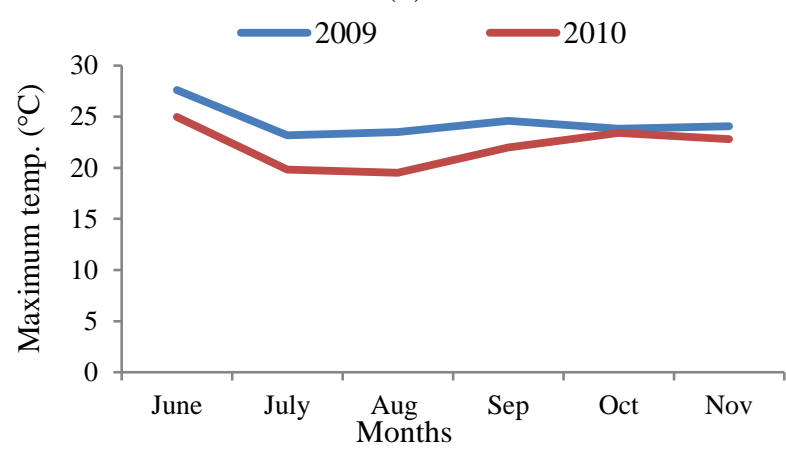

(c)

Figure 2 Rainfall (a), Minimum temperature (b) and maximum temperature (c) patterns during lentil growing at Akaki locations in 2009 and 2010 cropping seasons
Evaluating Lentil Genotypes for Growth and Yield Performance at Chefe Donsa

At Chefe Donsa location, the analysis of variance indicated that there were highly significant $(\mathrm{P} \leq 0.01)$ differences among genotypes for seed yield. Similarly, in this study there were highly significant $(\mathrm{P} \leq 0.01)$ differences among genotypes in days to number of $50 \%$ flowering, and days to number of $90 \%$ physiological maturity. The genotype Alemaya X FLIP 88-41L-02-AK14 gave the highest $\left(4189.1 \mathrm{~kg} \mathrm{ha}^{-1}\right)$ seed yield, followed by Alemaya X FLIP 88-41L-02-AK-6 (3859.4 $\left.\mathrm{kg} \mathrm{ha}^{-1}\right)$ in 2009 cropping season. They had yield advantage of 28.1 and $18 \%$ over the local check, respectively. The genotype Alemaya X FLIP 88-41L-02-AK-14 was the earliest number of days to $90 \%$ physiological maturity, which was 128.75 days at Chefe Donsa (Table 2). Genotype 87S93549 X EL-103-9-1 had yielded the highest seed yeilding (3262.5 kg ha-1), which accounts for $37 \%$ over the local check genotype. It's followed by the genotype Alemaya X FLIP 88-41L-02-AK-14 that had yield advantage of $27.6 \%$ over the local check at Chefe Donsa during the 2010 cropping season (Table 2).

Weather conditions had a significant role in the production and productivity of lentil at Chefe Donsa location. All genotypes, with the exception of the genotype 87S-93549 X EL-103-16, performed better than the local genotype (Table 2). Rainfall at the location was good, receiving $300 \mathrm{~mm}$ during 2009 and $500 \mathrm{~mm}$ during 2010 cropping seasons, and relatively higher temperature during the reproductive, seed filling period and harvesting time than the growth period tended to raise the yields of lentils (Figure 3).

Comparatively, Chefe Donsa is the location where better yield has been recorded for all genotypes considered in this particular study. This coincides with relatively favourable weather conditions appeared at the location. Therefore, this study recommends all the genotypes to be adopted for the location. However, Setotaw (2006) reported that in central highlands of Ethiopia, adoption of improved lentil varieties was found to be below expectations. Only $9 \%$ of lentil growers adopt improved varieties. In general, the limited adoption of improved lentil varieties is attributed to the current incidence of disease and insect problems.

Table 2 Mean seed yield and growth data of lentil genotypes tested at Chefe Donsa during 2009 and 2010 cropping seasons

\begin{tabular}{|c|c|c|c|c|c|c|c|c|}
\hline \multirow{2}{*}{ Genotype } & \multicolumn{4}{|c|}{2009 Cropping Season } & \multicolumn{4}{|c|}{2010 Cropping Season } \\
\hline & DF & DM & SY & $\Delta S Y$ & DF & DM & SY & $\Delta \mathrm{SY}$ \\
\hline 87S-93549 X EL-103-16 & $51.75^{\mathrm{b}}$ & $138.75^{\mathrm{ab}}$ & $1576.6^{\mathrm{C}}$ & -51.8 & $52^{\mathrm{c}}$ & $113.5^{\mathrm{ab}}$ & $2181.3^{\mathrm{b}}$ & -8.4 \\
\hline 87S-93549 X EL-103-9-1 & $57^{\mathrm{a}}$ & $134.75^{\mathrm{bc}}$ & $3575^{\mathrm{ab}}$ & 9.3 & $59.5^{\mathrm{a}}$ & $123^{\mathrm{ab}}$ & $3262.5^{\mathrm{a}}$ & 37.0 \\
\hline Alemaya X FLIP 88-41L-02-AK-14 & $58.25^{\mathrm{a}}$ & $128.75^{\mathrm{c}}$ & $4189.1^{\mathrm{a}}$ & 28.1 & $55.25^{\mathrm{b}}$ & $113^{\mathrm{b}}$ & $3039.1^{\mathrm{a}}$ & 27.6 \\
\hline Alemaya X FLIP 88-41L-02-AK-6 & $58^{\mathrm{a}}$ & $137.5^{\mathrm{ab}}$ & $3859.4^{\mathrm{ab}}$ & 18.0 & $55^{\mathrm{b}}$ & $125.5^{\mathrm{a}}$ & $2925^{\mathrm{a}}$ & 22.8 \\
\hline Local (Alemaya) & $57.75^{\mathrm{a}}$ & $143.5^{\mathrm{a}}$ & $3269.9^{b}$ & - & $58.5^{\mathrm{a}}$ & $123^{\mathrm{ab}}$ & $2381.3^{\mathrm{b}}$ & - \\
\hline $\mathrm{CV}(\%)$ & 1.84 & 3.76 & 15.21 & & 3.01 & 6.83 & 12.59 & \\
\hline LSD (0.05) & 1.57 & 7.75 & 755.08 & & 2.54 & 12.31 & 523.5 & \\
\hline
\end{tabular}

Means followed by the same letter within the same column are not significantly different from each other at $\mathrm{p}=0.05$ level of significance,

$\Delta \mathrm{SY}=$ Change in Seed Yield (\%), CV = Coefficient of variation, DF= Days to flowering, DM= Days to physiological maturity,

$\mathrm{LSD}=$ Least significant difference, $\mathrm{SY}=$ Seed Yield $\left(\mathrm{kg} \mathrm{ha}^{-1}\right)$ 
Table 3 Mean seed yield and growth data of lentil genotypes tested at Bishoftu during 2009 and 2010 cropping seasons

\begin{tabular}{|c|c|c|c|c|c|c|c|c|}
\hline \multirow{2}{*}{ Genotype } & \multicolumn{4}{|c|}{2009 Cropping Season } & \multicolumn{4}{|c|}{2010 Cropping Season } \\
\hline & DF & DM & SY & $\Delta \mathrm{SY}$ & DF & DM & SY & $\Delta \mathrm{SY}$ \\
\hline 87S-93549 X EL-103-16 & $40.75^{\mathrm{c}}$ & $84^{\mathrm{c}}$ & $1148.4^{\mathrm{a}}$ & 8.7 & $42.25^{\mathrm{c}}$ & $93.25^{\mathrm{a}}$ & $1493.8^{\mathrm{a}}$ & 8.1 \\
\hline 87S-93549 X EL-103-9-1 & $47.5^{\mathrm{a}}$ & $96^{\mathrm{a}}$ & $1195.3^{\mathrm{a}}$ & 13.2 & $48.5^{\mathrm{ab}}$ & $97.75^{\mathrm{a}}$ & $1525^{\mathrm{a}}$ & 10.4 \\
\hline Alemaya X FLIP 88-41L-02-AK-14 & $48^{\mathrm{a}}$ & $92.5^{\mathrm{b}}$ & $1470.3^{\mathrm{a}}$ & 39.2 & $45.5^{b}$ & $75^{\mathrm{a}}$ & $996.9^{b}$ & -27.8 \\
\hline Alemaya X FLIP 88-41L-02-AK-6 & $47^{\mathrm{a}}$ & $90.75^{\mathrm{b}}$ & $1323.4^{\mathrm{a}}$ & 25.3 & $46.25^{\mathrm{b}}$ & $96.5^{\mathrm{a}}$ & $1339.1^{\mathrm{ab}}$ & -3.1 \\
\hline Local (Alemaya) & $44.5^{b}$ & $92^{\mathrm{b}}$ & $1056.3^{\mathrm{a}}$ & - & $51.5^{\mathrm{a}}$ & $97.75^{\mathrm{a}}$ & $1381.3^{\mathrm{ab}}$ & - \\
\hline $\mathrm{CV}(\%)$ & 2.82 & 2.16 & 32.94 & & 4.76 & 21.12 & 20.42 & \\
\hline $\operatorname{LSD}(0.05)$ & 1.94 & 2.96 & 615 & & 3.027 & 29.25 & 414.55 & \\
\hline
\end{tabular}

Means followed by the same letter within the same column are not significantly different from each other at $p=0.05$ level of significance, $\Delta \mathrm{SY}=$ Change in Seed Yield $(\%), \mathrm{CV}=$ Coefficient of variation, $\mathrm{DF}=$ Days to flowering, $\mathrm{DM}=$ Days to physiological maturity,

LSD = Least significant difference, $\mathrm{SY}=$ Seed Yield $\left(\mathrm{kg} \mathrm{ha}^{-1}\right)$

Evaluating Lentil Genotypes for Growth and Yield Performance at Bishoftu

The differences among genotypes for grain yield were non-significant $(\mathrm{P}>0.05)$ at Bishoftu in 2009 cropping season (Table 3). However, all genotypes for grain yield had better in seed yield than the local check, Alemaya. Low productivity per unit area and low seed quality (small seeded, undesired color, low plumpness) were typical features of Ethiopian lentils (Korbu, 2009; MOARD, 2003). The genotype Alemaya X FLIP 88-41L02-AK-14 produced the highest (1470.3 $\mathrm{kg} \mathrm{ha}^{-1}$ ) seed yield of all the other lentil genotypes included in this particular study at Bishoftu in 2009 cropping season. Whereas, in 2010 cropping season at Bishoftu, genotype 87S-93549 X EL-103-9-1 produced the highest (1525 kg $\mathrm{ha}^{-1}$ ) seed yield (Table 3 ). This genotype had yield advantage of $10.4 \%$, followed by the genotype $87 \mathrm{~S}-93549$ X EL-103-16 with $8.1 \%$ over the local check. Similarly, differences among the genotypes in days to $50 \%$ flowering and days to $90 \%$ physiological maturity were highly significant $(\mathrm{P} \leq 0.01)$ in 2009 cropping season. However, there was no significant difference in days to number of $90 \%$ physiological maturity in 2010 cropping season. It was also pinpointed that genotype $87 \mathrm{~S}-93549 \mathrm{X}$ EL-103-16 was the earliest flowered and matured of all genotypes at Bishoftu, accounting for about 40 and 84 days, respectively, during 2009 cropping season. On the other hand, Alemaya X FLIP 88-41L-02-AK-14 was found to be the earliest matured lentil genotype taking only about 75 days, followed by the genotype Alemaya $\mathrm{X}$ FLIP 88-41L-02-AK-6 with about 96.5 days.

The current research finding indicated that the yields of lentil genotypes considered in this study were far below the anticipated value at Bishoftu location as the area is the potential area for pulse crop production. Relatively, the least amount of rainfall below $70 \mathrm{~mm}$ received, and the highest maximum temperature $\left(>25^{\circ} \mathrm{C}\right)$ during lentil growing season hampered the yields of lentil genotypes (Figure 4). Lentil is mainly grown in the highlands of Ethiopia where rainfall is usually high (Jarso et al., 2009). On the other hand, the impacts of minimum temperature on the yields of lentil genotypes across the testing locations did not as such affect the crop performance; given the lentil is cool season crop.

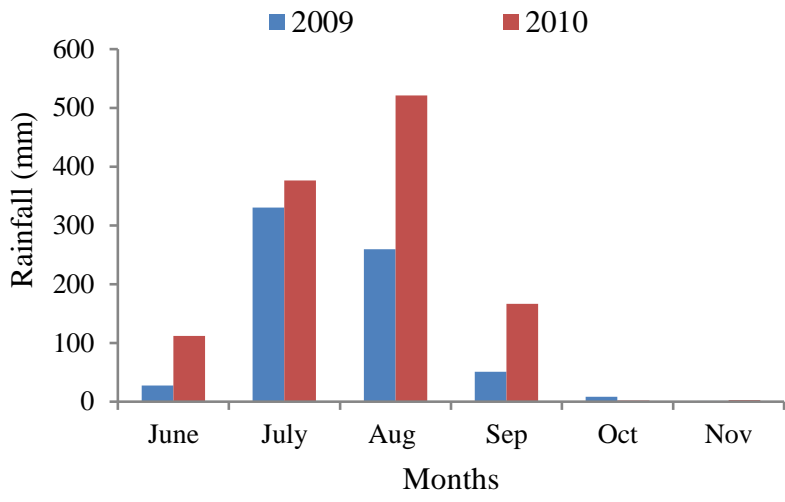

(d)

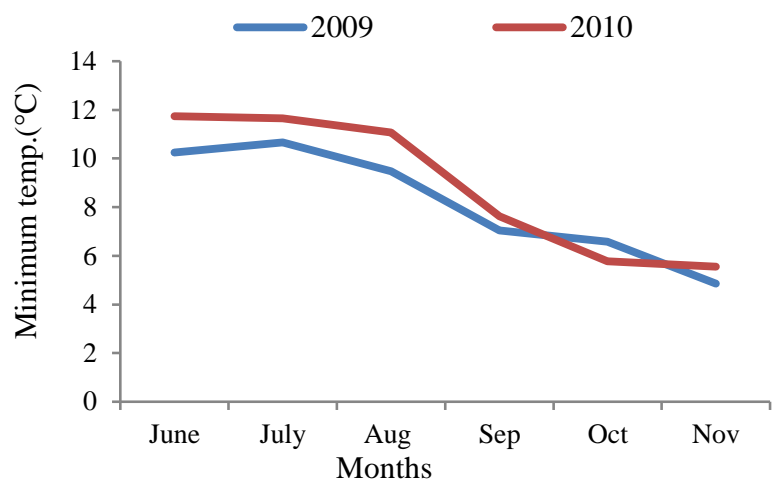

(e)

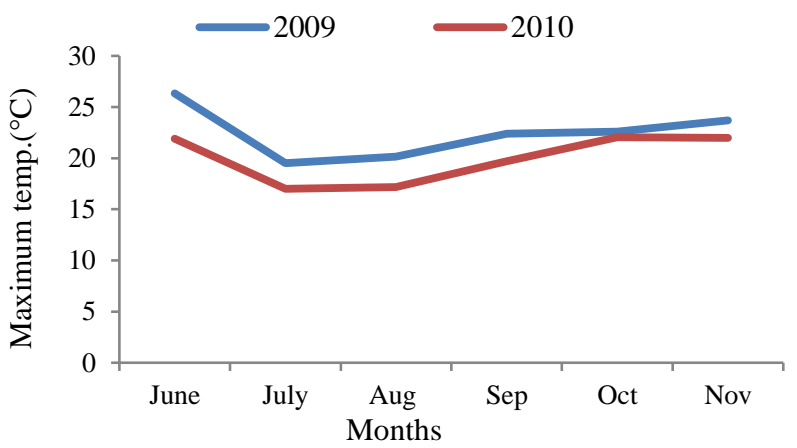

(f)

Figure 3 Rainfall (d), minimum temperature (e) and maximum temperature (f) pattern during lentil growing at Chefe Donsa location during 2009 and 2010 cropping seasons 


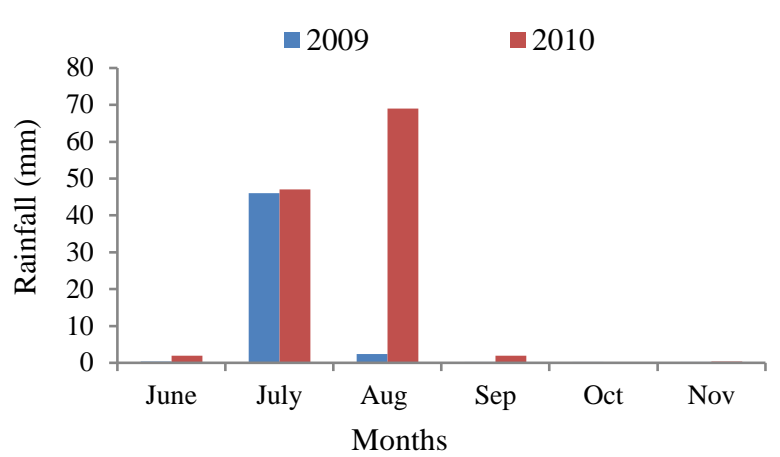

(g)

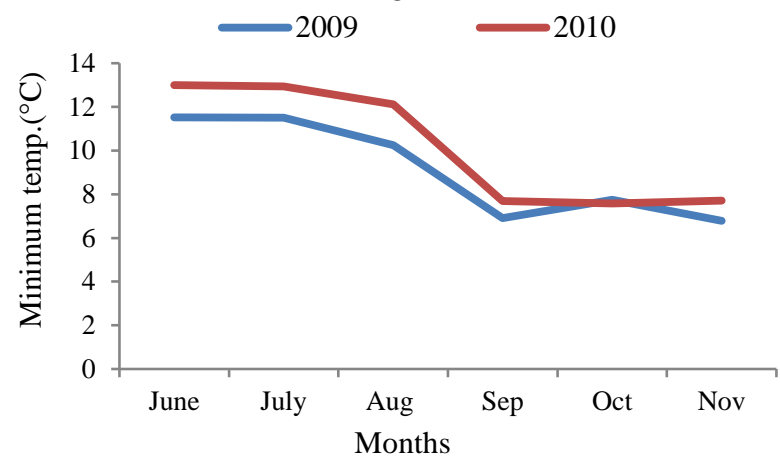

(h)

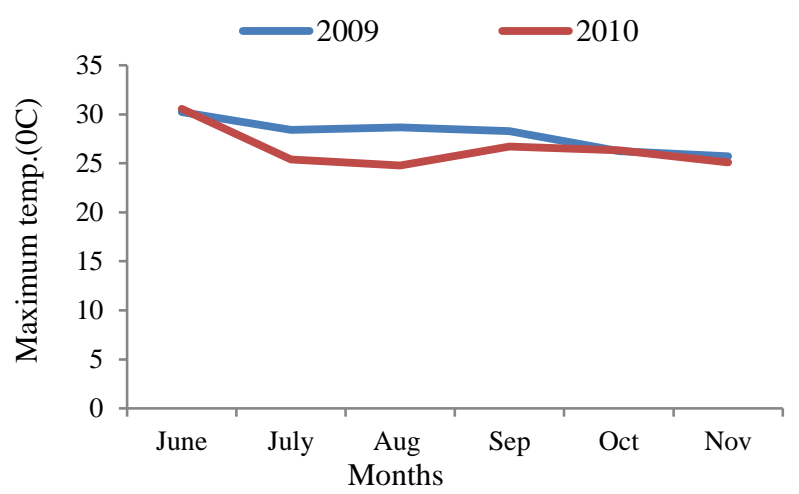

(i)

Figure 4 Rainfall (g), minimum temperature (h) and maximum temperature (i) pattern during lentil growing at Bishoftu location during 2009 and 2010 cropping seasons.

\section{Conclusions}

The study attempted to assess the growth and yield performance of five lentil genotypes in the Central Highlands of Ethiopia. The genotype 87S-93549 X EL103-9-1 gave the highest grain yields of 1985.90 and 2500 $\mathrm{kg} \mathrm{ha}^{-1}$ at Akaki in 2009 and 2010 cropping seasons, respectively. Yield variation between the cropping seasons might be the influence of weather conditions and other factors along with weather pattern. The genotype 87S-93549 X EL-103-16 was the earliest in days to $90 \%$ physiological maturity, accounting 98 and 109 days during 2009 and 2010 cropping seasons, respectively. The genotype Alemaya X FLIP 88-41L-02-AK-14 gave the highest (4189.1 kg ha-1) grain yield, followed by Alemaya X FLIP 88-41L-02-AK-6 with $3859.4 \mathrm{~kg} \mathrm{ha}^{-1}$ during 2009 cropping season at Chefe Donsa. They had yield advantage of 28.1 and $18 \%$ over the local check, respectively.
The genotype Alemaya X FLIP 88-41L-02-AK-14 was found to be the earliest in days to $90 \%$ physiological maturity, which was 128.75 days, whereas the genotype 87S-93549 X EL-103-9-1 had the highest (3262.5 $\left.\mathrm{kg} \mathrm{ha}^{-1}\right)$ grain yield, which was $37 \%$ over the local check, followed by the genotype Alemaya X FLIP 88-41L-02AK-14 that had yield advantage of $27.6 \%$ over the local check at Chefe Donsa during the 2010 cropping season. However, all genotypes performed well over the local check at Bishoftu. The lowest yields were recorded at Bishoftu during both cropping seasons. This could be due to many reasons such as rainfall and temperature and other abiotic and biotic factors. In conclusion, high yields of lentil genotypes were recorded at Chefe Donsa, followed by Akaki, and finally Bishoftu research station. This study mainly focuses on the impacts of climate events hindering the growth and yield performance of lentil crop in all the study areas considered. Nothing has been said about other factors which might affect the production of lentils in those study areas. This desires other studies to be accompanied in the areas.

\section{Acknowledgements}

It's our pleasure to thank Debre Zeit Agricultural Research Centre, Pulse Research Team, for its crop data for this particular work. Again, we would like to extend our sincere appreciation to all colleagues who contributed to this work in result interpretation and peer reviewing.

\section{References}

Abraham R. 2015. Lentil (Lens Culinaris Medikus) Current Status and Future Prospect of Production in Ethiopia. Advances in Plants and\& Agriculture Research 2(2): 00040.

Adsule RN, Kadam SS, Leung HK. 1989. Lentil. In: D.K. Salunkehe and S.S. Kadam (eds.) CRC hand book of world food legumes. (eds. D.K. Salunkehe and S.S. Kadam). Boca Raton, Florida, USA: CRC Press. 312 pp.

Anbessa Y, Bejiga G. 2002. Evaluation of Ethiopian chickpea landraces for tolerance to drought. Gen Res and Crop Evol. 49(6):557-64.

Bedard T, Risula D, Olekson A. 2010. Pulse Growers "Overview of the Canadian Pulse Industry 2009". Agriculture and Agri-Food Canada, Canada.

Brennan J, Aw-Hassan A, Quade K, Nordblom T. 2002. Impact of Ashutosh and Shiv, 2011. Research on Australian Agriculture, Economic Research Report No. 11, NSW Agriculture. 84 pp.

Cokkizgin A, Munqez JY. 2013. Lentil: Origin, Cultivation Techniques, Utilization and Advances in Transformation. Agricultural Science 1(1): 55-62.

Devasirvatham V, Gaur PM, Mallikarjuna N, Raju TN, Trethowan RM, Tan DKY. 2012. Effect of high temperature on the reproductive development of chickpea genotypes under controlled environments. Funct Plant Biol 39:10091018.

Dhuppar P, Biyan S, Chintapalli B, Rao S. 2012. Lentil Crop Production in the Context of Climate Change: An Appraisal. Indian Research Journal of Extension Education 2(Special Issue): 33-35.

Edossa F, Kassahun T, Endashaw B. 2007. Genetic diversity and population structure of Ethiopian lentil (Lens culinaris Medikus) landraces as revealed by ISSR marker. African. J. Biotechnol. 2(10):320-325. 
FAO 2014. FAO Statistical Database. Food and Agriculture Organization of the United Nations, USA.

FAO 2016. FAO Statistical Database. Available: http://www.fao.org(Accessed on: 12 April 2017).

FAOSTAT (Food and Agriculture Organization/Statistical Database). 2006. Agricultural Data on Primary Crops. Available:http://faostat.fao.org/faostat (Accessed on: 02 February 2018).

Frederick M, Cho S, Sarker A, McPhee K, Coyne C. 2006. Application of biotechnology in breeding lentil for resistance to biotic and abiotic stress. Euphytica 147(1-2): 149-165.

Getahun M. 2016. Review on Agronomic Practices for Improving Production and Productivity of Lentil in Ethiopia. Journal of Biology, Agriculture and Healthcare 6(13):102106.

Iqbal A, Khalil IA, Ateeq N, Khan N. 2006. Nutritional quality of important legumes. Food Chemistry 97(2): 331-335.

Jarso M, Korbu L, Gebeyehu S, Alemayehu F. 2009. Improved Crop Production Practices for Major Pulses of Ethiopia; a training manual prepared for training of trainers Organized by Rural Capacity Building Project (RCBP). Ministry of Agriculture and Rural Development. Addis Ababa, Ethiopia.

Joseph P, Gary W, Vincent H. 2014. Lentils: Trends in Production, Trade, and Price. Briefing No. 61, Policy Center, Agricultural Marketing, The U.S. Department of Agriculture (USDA), $M$ ontana State University and Montana State University Extension. Montana, USA. 6 pp.

Keneni G, Bekele E, Imtiaz M, Dagne K. 2012. Genetic vulnerability of modern crop cultivars: causes, mechanism and remedies. Int J Plant Res 2:69-79.

Korbu L. 2009. Improving Production and Productivity of Chickpea and Lentil in Ethiopia Production Manual. Melkasa, Ethiopia.
Kumar S, Thakur P, Kaushal N, Malik JA, Gaur P, Nayyar H. 2012. Effect of varying high temperatures during reproductive growth on reproductive function, oxidative stress and seed yield in chickpea genotypes differing in heat sensitivity. Arch Agron Soil Sci 59:823- 843.

Liang W, Carberry P, Wang G, Lü R, Lü H, Xia A. 2011. Quantifying the yield gap in wheat-maize cropping systems of the Hebei Plain, China. Field Crop Research, p185.

Mesfin K, Tekalign T. 2011. Indexing soil P to recommend for durum wheat in East Shewa, Oromiya Region. Report and Opinion 3(1): 7. Debre Zeit Agricultural Research Center, Debre Zeit, Ethiopia. http://www.sciencepub.net/report.

MOARD (Ministry of Agriculture and Rural Development). 2003. Lentil Development Plan Amharic version. Addis Ababa, Ethiopia.

Muehlbauer FJ, Cubero JI, Summerfield RJ. 1985. Lentil (Lens culinaris Medic.). pp. 266-311. In: Summerfield RJ \& Roberts EH (Eds.), Seed Legume Crops. Collins, 8 Grafton Street, London, UK.,

NMA (National Meteorology Agency) 2007. Annual Report on Temperature and Rainfall distribution for Akaki, Debre Zeit and Chefe Donsa. Addis Ababa, Ethiopia.

Ozdemir S. 2002. Seed legume crops. Hasad Publishing, Istanbul, Turkey, pp. 142.

Sarker A, Kumar S. 2011. Lentils in production and food systems in West Asia and Africa. International Center for Agricultural Research in the Dry Areas (ICARDA), Aleppo, Syria. Seed Legumes 57: 46-48.

SAS Institute. 2002. SAS System for Windows Release 9.2 Inc., Cary, NC, USA.

Setotaw Ferede T. 2006. Impact of technological change on housed production and food security in small holder agriculture; the case of wheat-tef based farming system in the central high lands of Ethiopia.

Sorecha EM, Kibret K, Hadgu G, Lupi A. 2017. Exploring the Impacts of Climate Change on Chickpea (Cicer arietinum L.) Production in Central Highlands of Ethiopia. Academic. Research. Journal and. Agricultural. Science. Research. 5(2):140-150. 